ーコミュニケーションー

\title{
プロトン導電性セラミックスを用いた硫化水素 熱分解ガスからの水素分離
}

\author{
岩原 弘育*, 安本 栄一”, 江坂 享男, 内田 裕之 ${ }^{\dagger}$
}

Hydrogen Separation from Pyrolyzed Hydrogen Sulfide Using Proton Conducting Ceramics Hiroyasu IWAHARA*, Eiichi YASUmoTo ${ }^{\dagger}$, Takao ESAKA ${ }^{\dagger}$ and Hiroyuki UCHIDA ${ }^{\dagger \dagger}$ Received July 9, 1990 ; Accepted October 8, 1990

\section{1. 楮言}

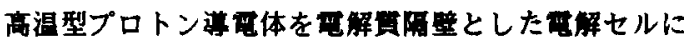
直流流を通ずると、水秦のみを電気化学的に造远させ

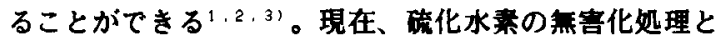
有効利用" が問题となっているが、本研究では先に当研

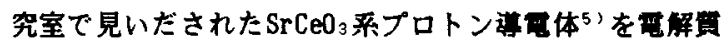
に用いて硫化水素の热分解混合ガスから水番を分崔回収 することが可能かどうかについて検討した。Fig.1はそ の原理を模式的に示したもので、このような方法により

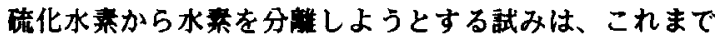
啹告されていない。

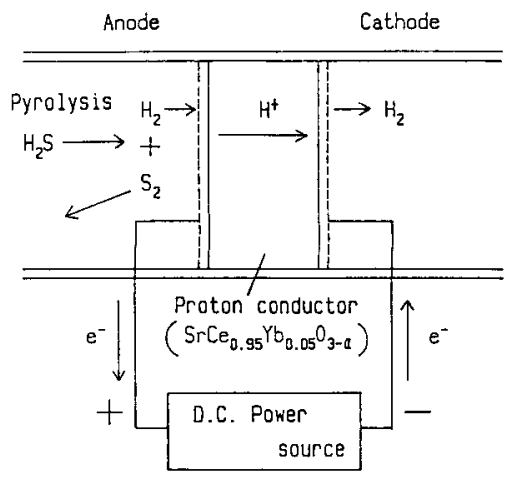

Fig. 1 Principle of hydrogen separation from pyrolyzed hydrogen sulfide.

名古屋大学工学部人工結晶研究施設 ( 程区不老町) Synthetic Crystal Research Lab., Faculty of Engineering, Nagoya University ( Fura-cho, Chikusa-ku, Nagoya 464 )

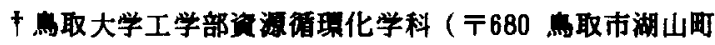
南4-101) Department of Environmental Chemistry and Technology, Faculty of Engineering, Tottori University ( Koyama-cho, Tottori 680) 护現在、大阪大学工学部応用化学科（テ565 吹田市山田 丘2-1) Department of Applied Chemistry, Faculty of Engineering, 0saka University ( 2-1 Yanada-oka, Suita, 565 )

Key words : Proton Conductor, Solid Electrolyte, Hydrogen Sulfide, Hydrogen Separation

\section{2. 実酸}

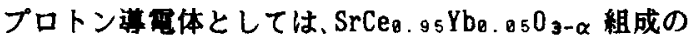
酸密な管状烧結体(TYK製,外径10ma，内径8nn，長さ180m) および、当研究室で拥製した円桖状烧結体（直径12na，厚 さ0.5m）を用いた。管状西解買には、Fig.2に示したよう

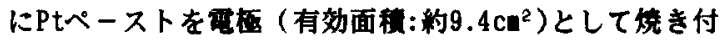

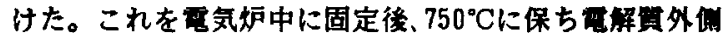
に硫化水秦ガスを、内梉にArキャリアガスを約30w1/min で流した。そしてこれに直洼垠流を通じ、内觔に抽出さ れる水来の量をガスクロマトグラフにより洞定した。円 整状解解筫では、片面に白金をもう一方の面に白金また はニッケルを中央部 $0.50 \mathrm{~cm}^{2}$ に姑き付けた。これをガラ スパッキングを介して碃製管ではさみつけ、2つのガス 要極室を持つテストセルを袖成し、溂定沮度 $700 \sim 800^{\circ} \mathrm{C}$

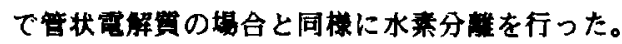

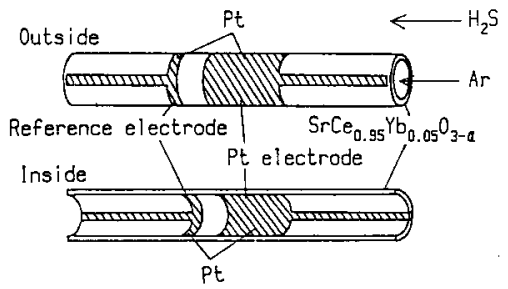

Fig.2 Schematic diagrams of hydrogen pump. (Tubular electrolyte)

\section{3. 結果と考察}

硫化水来の勄分解反応は一般に(1) 式で与えられる。 $\mathrm{H}_{2} \mathrm{~S} \rightleftharpoons \mathrm{H}_{2}+1 / 2 \mathrm{~S}_{2}$

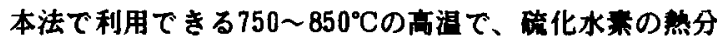
解によって発生する水来源度を愣定したところ、(1)式の 平衙定数から得られる計策值に近い值 $\left(800^{\circ} \mathrm{C}\right.$ で約 $\left.6 \%\right)$ を とることが分かった。

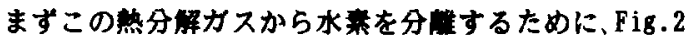

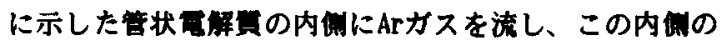
植をマイナス梅としてセルに通電したところ、Ar中に

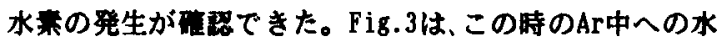

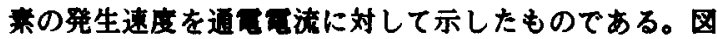
中の破總は、Faraday則から計望した理謒水来発生速度で

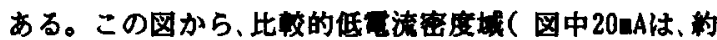

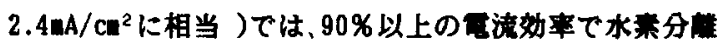
ができることが分かる。またこのセルは少なくとも15時 


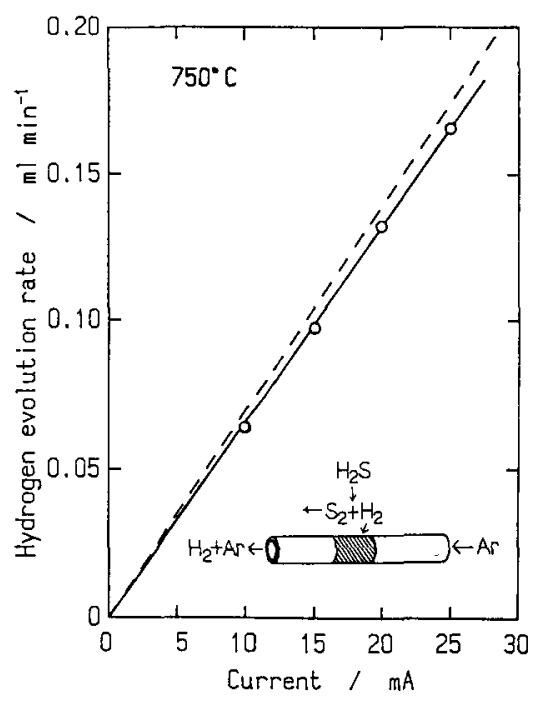

Fig. 3 Hydrogen evolution rate vs. current relation at $750^{\circ} \mathrm{C}$.

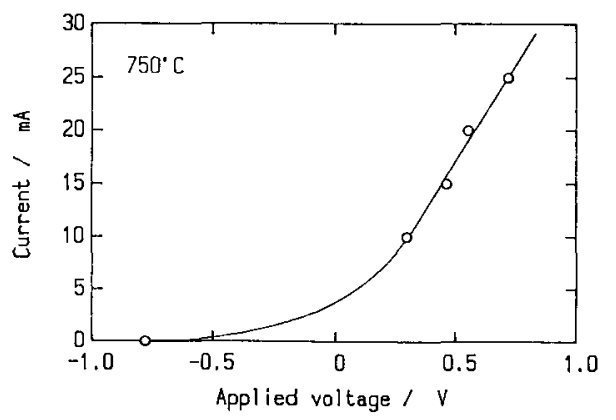

Fig. 4 Current-voltage relation of the hydrogen pump at $750^{\circ} \mathrm{C}$ ( Tubular electrolyte).

間程度は、安定に水素を分離できた。このような安定作 孟時の要流と電圧の関係㥀線（Fig.4）となりその模 轴への外㨉值から求めた分解電圧は、ほぼ0.0Vである。 このことは $\mathrm{H}_{2} \mathrm{~S}$ 直接電解が起きているのではなく㠇分 解により生じた水秦が電気化学的に透遇していることを 示している。また直緗の㑯きから得られる直流抵抗值は、 交流抵抗值にほほ見合うものであり、このセルの抵抗は 主としてプロトン逃西体のオーム抵抗によるものであっ た。

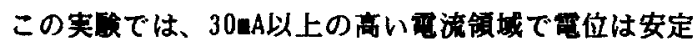
せす䃘流効率がかなり低下したので、その原因について Fig.5 中に示したような円盤状西解買を用いたセルで嘆 討した。

まず确化水来に予め水来ガスを40\%加えて通四してみ

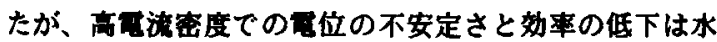
莱無添加の場合と变わらなかった。このことは、上記の

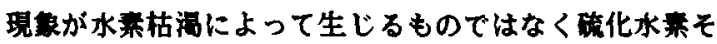

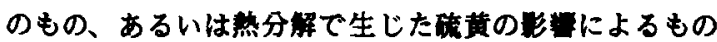
であることを付けている。実懸、この现象の生じたセ

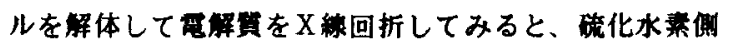
の白金苑極の一部が硫化白金(PtS) に変化していること が分かった。

そこでこの電厚上の硫黄の狸㗍を除去することを考え て、碳化水素中に水蒸気を含ませてみた。水寈気分圧を 変化させても電流効率に大きな差はなかったが、通西時 の霓位は水蒸気を入れない場合よりもかなり安定するこ とが分かった。これは、セル内で破水秦の第分解によ って生じる硫黄が、水蒸気と反忘して二酸化硫黄となっ て取り除かれるためであううと考えられた。

次にアノード材について模討した。Fig.5に、白金と二 ッケルを用いた場合の水秦発生速度を比較して示した。 ニッケルでは白金よりも西流奻事が幾分低下したものの、 安定性に閉しては、両者にほとんど差は見られなかった。 したがって、実際の使用には安価なニッケルが有利であ ると考えられる。

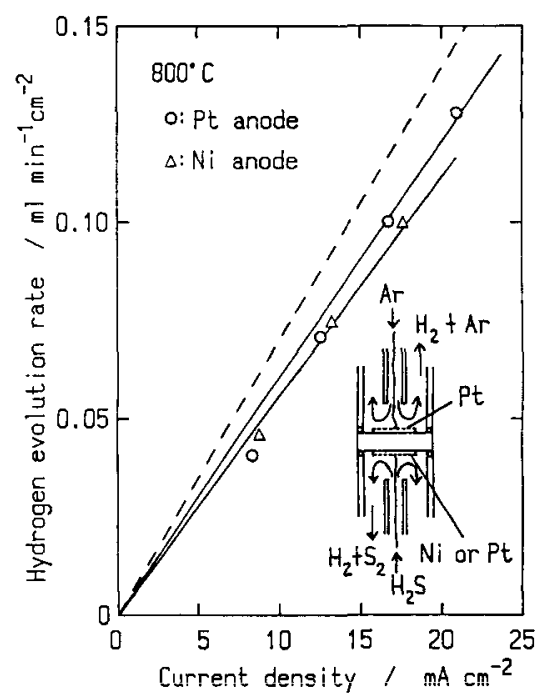

Fig. 5 Hydrogen evolution rate vs. current density relations for different cathode materials.

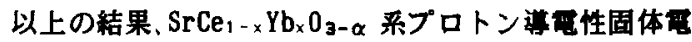

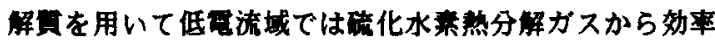
よく水秦を分椎できることが分かった。また既極には、 白金よりも安晌なニッケルが通していることが分かった。

\section{文部}

1) H. Iwahara, H.Uchida and S. Tanaka, Solid State Ionics, 9/10, 1021 (1983)

2) H.Iwahara, T.Esaka, H.Uchida, T. Yanauchi and K.ogaki, Solid State Ionics, 18\&19, 1003 (1986)

3）岩原弘育，内田枌之，高岛和行，気化学，57（10） 996 (1989)

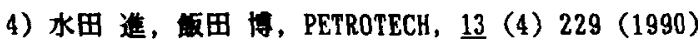

5) H.Iwahara, T.Esaka, H. Uchida and N. Maeda, Solid State Ionics, 3/4, 359 (1981) 